\title{
AKIBAT HUKUM SERTA PENYELESAIAN TERHADAP HARTA BERSAMA BERDASARKAN HUKUM PERKAWINAN
}

\author{
Ida Ayu Putu Kristanty Mahadewi, Fakultas Hukum Universitas Udayana, \\ E-mail: dayukristantyy@gmail.com \\ Dewa Nyoman Rai Asmara Putra, Fakultas Hukum Universitas Udayana, \\ E-mail: dewar2566@gmail.com
}

doi: https://doi.org/10.24843/KS.2020.v09.i01.p10

\begin{abstract}
ABSTRAK
Tujuan penelitian untuk mengkaji akibat hukum serta penyelesaian terhadap harta bersama berdasarkan hukum perkawinan apabila terjadi perceraian dan pemisahan harta bersama karena suatu hal. Penelitian ini menggunakan metode penelitian hukum normative, yakni suatu penelitian yang berdasarkan pada pendekatan perundang-undangan, bahan pustaka, putusan pengadilan dan ketentuan yang sebagaimana mestinya. Serta teknik pengumpulan data dilakukan dengan studi dokumen. Hasil studi menunjukkan bahwa dengan adanya suatu perjanjian dalam perkawinan maka harta benda dan harta bersama dari kedua pihak akan memiliki kepastian hukum yang tetap jika dilihat dari perspektif hukum. Penyelesaian harta bersama biasanya dilakukan dengan cara pemisahan harta benda kedua belah pihak. Penyelesaian perkara mengenai pembagian harta bersama yang terbaik adalah dilakukan dengan cara kekeluargaan. Penyelesaian permasalahan mengenai pemisahan harta bersama melalui pengadilan, juga bisa diusulkan melalui pengajuan gugatan sendiri oleh pihak yang berperkara maupun perantara melalui pengacara hukum. Dan permohonan mengenai pemisahan harta bersama tidak bisa diajukan bersamaan dengan gugatan cerai.
\end{abstract}

Kata Kunci: Perkawinan, Akibat Hukum, Penyelesaian Sengketa, dan Harta Bersama.

\begin{abstract}
The purpose of this study is to examine the legal consequences and the settlement of joint assets based on marriage law if the event of divorce and separation of joint assets for some reason. This study uses a normative legal research method, which is a study based on a statutory approach, library materials, court decisions and appropriate provisions. As well as data collection techniques carried out by document study. The results of the study show that with agreement in marriage, the property and joint assets of the two parties will have permanent legal certainty from a legal perspective. Settlement of joint assets is usually carried out by familial way. The settlement of problems regarding the separation of joint assets through the court, can also be proposed through filing a lawsuit by the litigant or intermediary through a lawyer. And applications regarding the separation of joint assets cannot be filed at the same time as a divorce suit.
\end{abstract}

Key Words: Marriage, Legal Consequences, Dispute Settlement, and Joint Assets. 


\section{Pendahuluan.}

\subsection{Latar Belakang Masalah}

Semua individu akan saling memerlukan serta saling bersosialisasi dengan yang lainnya, salah satu contohnya adalah dengan melangsungkan perkawinan. ${ }^{1}$ Melalui perkawinan akan terwujud suatu keluarga yang akan melahirkan keturunan. Perjanjian kawin adalah suatu penyimpangan pengaturan harta kekayaan suami istri berdasarkan pada hukum yang berlaku. Dengan dilangsungkan nya perkawinan maka akan ada kepastian hukum terhadap sesuatu yang sudah diperjanjikan baik dari pihak suami maupun istri untuk melaksanakan suatu perbuatan hukum. ${ }^{2}$ Masalah dalam perjanjian kawin yang sering terjadi adalah masalah pada pencatatan perkawinan yang akan berdampak pada perjanjian pemisahan harta kedua belah pihak. Didalam Pasal 29 Undang-Undang No. 16 Tahun 2019 Tentang Perubahan atas Undang-Undang Nomor 1 Tahun 1974 Tentang Perkawinan (selanjutnya sebut UU Perkawinan), perjanjian kawin dibentuk sebelum, ataupun selama perkawinan berlangsung. Perkawinan merupakan salah satu jalan untuk membangun kehidupan rumah tangga serta untuk memiliki garis keturunan. ${ }^{3}$ Didalam perkawinan tentu saja ada harta kekayaan dan harta bersama. Harta kekayaan dalam perkawinan merupakan suatu wujud nyata dari hasil kerja keras dalam rumah tangga sebagai modal kelangsungan hidup berkeluarga yang diperoleh oleh suami istri yang disebut dengan harta bersama ${ }^{4}$.

Diberlakukannya Undang-Undang No. 16 Tahun 2019 Tentang Perubahan atas Undang-Undang Nomor 1 Tahun 1974 Tentang Perkawinan bertujuan untuk penyempurnaan pengaturan dibidang hukum keluarga. ${ }^{5}$ Pasal 119 KUH Perdata merumuskan semenjak perkawinan dilaksanakan, maka hukum yang belaku akan membentuk harta kekayaan yang sempurna diantara kedua pihak, selama tidak ada menentukan hal lain didalam perjanjian tersebut. Pada Pasal 35 ayat (1) UU Perkawinan menegaskan kekayaan yang didapatkan selama perkawinan akan membentuk harta milik bersama. Kemudian dilanjutkan di ayat (2) yang merumuskan harta yang di bawa setiap pihak yang didapatkan sebagai warisan ataupun yang lainnya, dimana dibawah kekuasaan setiap pihak yang bersangkutan. Harta dalam perkawinan dibedakan menjadi tiga macam yakni harta bersama, harta bawaan dan juga harta perolehan. ${ }^{6}$ UU Perkawinan yang memuat mengenai status hukum harta perkawinan, menyatakan bahwa harta yang merupakan hak milik dari masing masing pihak memiliki status hukum sama. Pengaturan perjanjian perkawinan didalam UU Perkawinan biasanya praktik perkembangannya dapat menimbulkan masalah jika setiap pihak tidak melaksanakan kewajiban mereka sebelumnya.

1 Rahajeng, Pebriana Putu. "Fungsi Perjanjian Perkawinan Terhadap Status Kepemilikan Harta Pada Perkawinan Campuran", Kertha Semaya: Journal Ilmu hukum 6, No.11, (2018): 2.

2 Makangiras, Aris Siswanto. "Prinsip-prinsip Hukum Harta Bersama Dalam Perkawinan Berdasarkan UU Nomor 1 Tahun 1974." Lex Privatum 2, no. 1 (2014): 116.

3 Ismatllah, Dedi., Hukum Perdata Islam Indonesia (Bandung, Pustaka Setia, 2011), 32.

4 Murniati, Rilda. "Pembaharuan Hukum Perjanjian Perkawinan Dan Akibat Hukumnya Terhadap Harta Dalam Perkawinan", Jurnal Hukum Jatiswara 33, No. 3, (2018): 367.

5 Istrianty, Annisa, and Erwan Priambada. "Akibat Hukum Perjanjian Perkawinan Yang dibuat Setelah Perkawinan Berlangsung." Privat Law 3, no. 2 (2016): 84.

6 Muhammad, Abdulkadir. Hukum Perdata Indonesia, (Bandung, PT Citra Aditya Bakti, 2014), 109. 
Kajian teoritis yang menyangkut masalah penyelesaian harta bersama terlihat sangat gampang untuk di laksanakan, namun pada kenyataan nya pasca kedua pihak bercerai, selain permasalahan hak untuk mengasuh anak, masalah yang rumit dan sering tidak terselesaikan yaitu mengenai pemisahan harta bersama. Hal lain yang paling sering terjadi di dalam masyarakat manakala jika salah satu pihak meninggal dan tidak memiliki anak dari hasil perkawinannya, kemudian melaksanakan perkawinan dengan Warga Negara Asing maka sering kali ahli waris dari salah satu pihak merasa tidak adil bahkan tidak setuju untuk memberikan bagian warisannya meskipun sudah ada bukti kuat yang menunjukkan tentang pemilik harta bersama selama perkawinan. Walaupun sudah ada putusan dari Pengadilan mengenai bagaimana status harta bersama untuk dibagi pada setiap pihak, pada kenyataannya tidak segera dilaksanakan. Berdasarkan pada fakta hukum yang sudah dijelaskan dan sudah terjadi dalam kehidupan masyarakat, terdapat berbagai macam masalah yang terkait mengenai pembagian harta bersama yang dipandang sangat mudah tetapi pada kenyataannya rumit untuk diselesaikan hingga sering terjadi konflik dalam pihak keluarga. Lantaran banyaknya berbagai macam masalah dalam kehidupan masyarakat di atas, dengan demikian penelitian ini akan mengkaji bagaimana akibat hukum serta Penyelesaian terhadap harta bersama didalam perjanjian kawin dilihat dari UU Perkawinan dan KUH Perdata.

Berkaitan dengan state of the art, menurut penulis belum pernah ditemukan tulisan dengan judul dan pokok permasalahan yang sama. Namun, ditemukan ada beberapa penelitian atau karya ilmiah yang memiliki kemiripan tetapi dengan permasalahan yang berbeda. Penelitian yang dimaksud yaitu dengan judul "PrinsipPrinsip Hukum Harta Bersama Dalam Perkawinan Berdasarkan UU Nomor 1 Tahun 1974 oleh Aris Siswanto Makangiras. Penelitian ini memiliki keterkaitan mengenai Harta Bersama. Dalam penelitian tersebut berfokus pada bentuk dari harta bersama dalam perjanjian perkawinan, dan manfaat dari perjanjian perkawinan terhadap harta dalam perkawinan. Sedangkan dalam penelitian ini, yang penulis fokuskan mengenai bagaimana akibat hukum serta penyelesaian dari harta bersama berdasarkan pada Hukum Perkawinan. Jika dilihat dari kajian dalam penelitian tersebut terdapat perbedaan dalam rumusan masalah sehingga memiliki maksud, tujuan dan hasil analisis yang berbeda. Maka dengan demikian penelitian ini penting untuk dibahas agar menambah wawasan dan mengetahui lebih lanjut mengenai bagaimana akibat hukum serta penyelesaian terhadap harta bersama dalam perjanjian kawin berdasarkan pada Hukum Perkawinan.

\subsection{Rumusan Masalah}

1. Apa akibat hukum dari harta bersama didalam perjanjian kawin dilihat dari UU No. 1 tahun 1974 dan KUH Perdata?

2. Bagaimanakah penyelesaian masalah harta bersama didalam perjanjian kawin berdasarkan pada UU No. 1 tahun 1974 dan KUH Perdata?

\subsection{Tujuan Penulisan}

Berdasarkan permasalahan hukum diatas maka tujuan dari penulisan jurnal ini, yaitu untuk mengetahui dan menganalisis tentang akibat hukum serta penyelesaian masalah harta bersama dalam perjanjian kawin dilihat dari perspektif Undang-Undang No. 16 Tahun 2019 Tentang Perubahan atas Undang-Undang Nomor 1 Tahun 1974 Tentang Perkawinan dan KUH Perdata. 


\section{Metode Penelitian.}

Bentuk penelitian ilmiah yang dipergunakan yaitu penelitian hukum normatif, dimana penelitian hukum yang berdasar pada pendekatan perundang-undangan, aturan hukum, konsistensi, penjelasan pasal dan mengkaji hukum tertulis dari berbagai aspek kemudian dapat dijadikan sebagai acuan dalam penerapan hukum maupun implementasinya. Tipe penelitian ini yaitu penelitian deskriptif, mengenai aspek yang dapat dikaji berdasarkan dengan peraturan perundang-undangan dan serta putusan lembaga peradilan sebagai dasar maupun acuan kajian penelitian ilmiah ini. ${ }^{7}$ Data yang dipergunakan pada penelitian ilmiah bersumber dari data sekunder. Data sekunder yang dimaksud dalam jurnal ini, yakni: peraturan perundangundangan, bahan pustaka, putusan pengadilan (bahan primer), bahan hukum sekunder dan juga bahan hukum tersier. Teknik pengumpulan data sekunder dilakukan dengan studi dokumen. Setelah data yang telah terkumpul selanjutnya akan dianalisis. Analisis dalam jurnal ini memiliki tujuan untuk mengimplementasikan data yang sudah dibuat secara teratur dan akan diberikan suatu penjelasan. Data sekunder dalam jurnal ini analisis data yang digunakan dalam penelitian adalah analisis kualitatif.

\section{Hasil dan Pembahasan.}

3.1 Akibat Hukum dari Harta Bersama dalam Perjanjian Kawin ditinjau dari Undang-Undang No. 16 Tahun 2019 Tentang Perubahan atas Undang-Undang Nomor 1 Tahun 1974 Tentang Perkawinan dan KUH Perdata.

Harta kekayaan di sebuah perkawinan sesungguhnya merupakan suatu modal dalam keluarga untuk menunjang pembinaan dalam keluarga. Harta bersama dan harta kekayaan merupakan sebagai modal utama dalam suatu kehidupan keluarga yang harus dijaga keutuhannya. Harta kekayaan akan terbentuk menjadi harta bersama selama perkawinan ini dilangsungkan, kecuali para pihak menentukan untuk pemisahan harta kekayaannya. ${ }^{8}$ Ini terlihat pada Pasal 35 UU No. 1 tahun 1974 tentang Perkawinan merumuskan suatu kekayaan dalam bentuk apapun itu yang diperoleh pada saat perkawinan akan terbentuk menjadi harta bersama. Kenyataannya terkadang pihak yang akan menikah tidak memikirkan terkait bagaimana status dari harta bawaan dan harta yang diperoleh setiap pihak setelah perkawinan, karena tidak ada pihak yang menginginkan perkawinannya terputus dan berujung perceraian. UU No. 1 tahun 1974 tentang Perkawinan dan KUH Perdata hanya mengatur tentang pengertian dari harta benda didalam suatu perkawinan, namun tidak memaparkan penjelasan yang tegas dan rinci. Apabila dipahami makna dari Pasal 35 yang terdiri dari 2 ayat yang menetapkan harta benda didalam perkawinan terdiri dari harta bersama serta harta bawaan. Pihak Suami maupun pihak istri dalam perkawinan dapat mengatur harta benda dan harta bersama mereka secara terpisah sesudah masuk kedalam ikatan perkawinan. Setelah terpisahnya harta benda dalam keluarga

Muhammad, Abdulkadir. Hukum dan Penelitian Hukum. (Bandung, PT Citra Aditya Bakti, 2014), 115.

8 Kurniawan, Muhamad Beni. "Konsep Pembagian Harta Bersama Berdasarkan Kontribusi Dalam Perkawinan." AHKAM: Jurnal Ilmu Syariah 17, no. 2 (2017): 358 
kemudian konsekuensinya adalah setiap pihak suami maupun istri memiliki hak untuk mengelola sendiri harta benda nya. Didalam pemisahan harta bersama, kedua belah pihak terkadang harus mengikhlaskan sebagian hak yang dimiliki untuk mencapai kesepakatan bersama yang mufakat. ${ }^{9}$ Kemudian untuk membiayai keperluan rumah tangga atau keluarga biasanya menjadi kewajiban dari pihak suami ataupun kedua belah pihak yang menanggung bersama. Pembagian harta benda dan harta bersama ini dilimpahkan dalam suatu perjanjian kawin yang khusus dibuat untuk mengatur harta bersama tersebut. Berdasarkan dengan ketentuan tersebut maka perjanjian kawin dapat disusun agar setiap pengelompokan dari harta benda ataupun harta bersama menurut UU yang berlaku ditiadakan.

Peraturan hukum yang diterapkan di Indonesia yang memuat bahwa setiap harta yang didapat pada saat perkawinan itu berjalan dengan baik dapat membentuk harta bersama tanpa mengecualikan maupun memisahkan pihak yang mencari nafkah ataupun mendapatkan harta benda tersebut dan siapa yang terdaftar, dan selama harta benda itu bukanlah merupakan harta bawaan didalam kepemilikan harta bersama tersebut. ${ }^{10}$ Jika dilihat dari KUH Perdata, maupun UU Perkawinan rupanya tidak dibahas bagaimana harta bersama atas nama seorang, terkecuali kepengurusan harta bersama yang dibentuk pada masa perkawinan. Dalam pasal 164 KUH Perdata mengatur apabila dijanjikan sesuatu hasil dari penghasilan kedua belah pihak, maka mengenai tentang harta kekayaan secara utuh serta kesatuan untung rugi nya tidak akan terjadi persatuan. Berdasarkan dari ketentuan tersebut maka kesimpulannya bahwa setelah adanya suatu perjanjian dalam perkawinan maka harta benda dan harta bersama dari kedua pihak akan memiliki kepastian hukum yang tetap pula jika dilihat dari perspektif hukum. Kedua belah pihak harus mentaati dan menghormati segala isi perjanjian kawin karena sesuatu yang mengenai pemisahan harta yang sudah jelas dipisahkan, dan juga harta lainnya yang timbul setelah perjanjian tersebut tetap terpisah satu dengan yang lainnya sehingga tidak ada yang status nya adalah harta bersama. Apabila seandainya terjadi pemutusan hubungan atau perceraian, maka pemisahan harta bersama dapat diselesaikan menggunakan cara kekeluargaan. Dalam pemisahan harta bersama berdasarkan pada hukum yang berlaku bukanlah suatu hal yang mudah, karena pada prinsipnya didalam pemisahan harta benda dan harta bersama adalah sesuatu yang dapat dicapai dengan cara musyawarah berdasarkan pada prinsip keimanan, keadilan, keseimbangan dan yang lainnya. ${ }^{11}$

Salah satu contohnya adalah Putusan Mahkamah Konstitusi No. 69/PUUXII/2015 dimana keinginan pemohon untuk membeli rumah (rusun) di Jakarta. Pemohon menegaskan bahwa setelah menabung cukup lama dapat melunasi rumah tersebut. Akan tetapi rumah tersebut tidak kunjung diberikan dan kemudian perjanjian untuk penyerahan rusun tersebut dibatalkan secara sepihak oleh pihak pengembang dengan alasan suami pemohon adalah warga negara asing. Pengembang memiliki alasan dengan menyatakan hal yang mereka lakukan sudah sesuai dengan Pasal 36 Ayat (1) UU No. 5 Tahun 1960 dan Pasal 35 Ayat (1) UU Perkawinan yang menyatakan bahwa, seseorang yang kawin dengan warga Negara Asing dilarang untuk membeli tanah dan atau bangunan dengan status Hak Guna Bangunan. Dan menurut pemohon ketentuan Pasal 21 Ayat (1), Ayat (3) dan Pasal 36 Ayat (1) UU

9 Faizal, Liky. "Harta bersama dalam Perkawinan." Ijtimaiyya: Jurnal Pengembangan Masyarakat Islam 8, no. 2 (2015): 94

10 Firdawaty, Linda. "Filosofi Pembagian Harta Bersama." ASAS 8, no. 1 (2016): 89

11 Ibid., 101. 
Perkawinan melanggar konstitusi dan membuat Pemohon sebagai warga Negara Indonesia yang sah merasa sangat dirugikan perjanjian perkawinan, karena hak pemohon untuk menikah dengan Warga Negara Asing dan bahkan sudah dilakukan sesuai dengan hukum yang berlaku. Dengan demikian, perjanjian perkawinan yang dibuat pada waktu dan selama berlangsungnya perkawinan secara hukum dapat mengakibatkan terjadinya pemisahan harta dari harta perkawinan menjadi harta pribadi. ${ }^{12}$ Dilihat dari contoh Putusan Mahkamah Konstitusi ini, tidak adanya aturan yang tegas mengenai hal tersebut. Di satu sisi pemohon menganggap beberapa ketentuan dari Pasal yang terdapat pada UU Perkawinan melanggar konsitusi sedangkan disisi lain Pengembang memiliki alasan dengan menyatakan hal yang mereka lakukan sudah sesuai dengan ketentuan Pasal. Dalam hal state of the art, penulis belum pernah menemukan tulisan dengan pokok permasalahan yang sama. Namun, ditemukan ada beberapa penelitian atau karya ilmiah yang memiliki kemiripan tetapi dengan permasalahan yang berbeda. Penelitian tersebut dengan judul "Hukum Harta Bersama Ditinjau Dari Perspektif Undang-Undang Perkawinan Dan KUH Perdata" oleh Evi Djuniarti. Penelitian ini memiliki keterkaitan mengenai Harta Bersama. Pada penelitian tersebut hanya mengkaji mengenai pengertian dan perbedaan Harta Benda Bersama dan Harta Benda Bawaan dalam Perkawinan. Sedangkan dalam penelitian ini penulis bukan hanya menjelaskan hal tersebut tetapi juga mengkaji bagaimana akibat hukum dari harta bersama dan disertakan dengan contoh Putusan Mahkamah Konstitusi yang memperkuat penelitian ini. Maka dengan demikian, penelitian ini menarik untuk dibahas karena bukan hanya mengetahui pengertian dan perbedaan dari harta bersama tetapi juga untuk mengetahui bagaimana akibat hukum dari harta bersama dan contoh yang sudah pernah terjadi didalam masyarakat.

\subsection{Penyelesaian Masalah Harta Bersama Didalam Perjanjian Kawin Berdasarkan Pada UU No.1 tahun 1974 dan KUH Perdata.}

Harta bersama merupakan kekayaan yang didapatkan semasa suatu perkawinan dilangsungkan. Terhadap harta bersama kedua pihak dapat bertindak dari masingmasing pihak. ${ }^{13}$ Perlindungan hukum harta bersama dialam perjanjian perkawinan adalah berlaku pada saat perkawinan tersebut dilangsungkan. Penyelesaian Harta Bersama biasanya dilakukan dengan cara pemisahan harta benda. Terkadang penyelesaian harta bersama menimbulkan beberapa konflik diantara pihak yang bersangkutan. Pelaksanaan pembagian harta bersama dilakukan karena ada berbagai faktor yang bermacam-macam, di antaranya kewajiban antara kedua belah pihak yang tidak dilaksanakan secara baik sehingga menimbulkan permasalahan dan juga dampak terburuk nya yaitu terputusnya hubungan perkawinan. Penyelesaian perkara mengenai pembagian harta bersama yang terbaik adalah dilakukan dengan cara damai atau kekeluargaan, namun terkadang dengan cara tersebut sering terjadi konflik para pihak yang dimana salah satu pihak merasa keberatan atas pembagian harta nya. Kemudian proses penyelesaian perselisihan mengenai pemisahan harta bersama dalam perjanjian kawin akibat perceraian ada dua kemungkinan, dengan gugatan diajukan sesudah putusan cerai yang memiliki kepastian hukum ataupun gugatan

12 Murniati, Rilda, Op.Cit., 375

13 Wahyudi Tri Abdullah. Hukum Acara Peradilan Agama. (Bandung, CV. Mandar Maju, 2018), 60 
harta bersama yang diusulkan para pihak dengan gugatan perceraian. ${ }^{14}$ Kedua belah pihak harus menyerahkan gugatan terpisah ketika sesudah putusan perceraian ditetapkan oleh pengadilan. Permohonan mengenai pemisahan harta bersama tidak bisa diajukan bersamaan dengan gugatan cerai. ${ }^{15}$

Penyelesaian permasalahan mengenai pemisahan harta bersama melalui pengadilan, juga bisa diusulkan melalui pengajuan gugatan sendiri oleh pihak yang berperkara maupun perantara melewati pengacara hukum. Penyidikan terhadap pemisahan harta bersama dapat dilaksanakan sesudah memeriksa dari gugatan perceraian. Bila gugatan perceraiannya tidak diterima oleh pengadilan, dengan demikian pemisahan harta bersamanya juga akan tidak di terima oleh pengadilan. Dikarenakan pemisahan harta bersama mengacu pada hal tersebut. Terkecuali jikalau untuk pemisahan harta, yang dimana diantara para pihak di khawatirkan dapat menghilangkan bukti yang ada dan merugikan pihak lain. ${ }^{16}$ Ketentuan hukum mengenai harta bersama akibat kedua belah pihak bercerai yaitu mengunakan hukum yang berlaku di masyarakat. Sehingga didalam perjanjian perkawinan harta kekayaan merupakan suatu objek dalam perjanjian kawin. Dan kemudian dalam hal keadaan harta bersama pasca perceraian, didalam putusan hakim bahwa besarnya bagian untuk masing-masing pihak janda ataupun duda dalam pemisahan harta yang telah putus akibat bercerai adalah separuh dari harta bersama menjadi hak bagi masingmasing pihak selama tidak ada perjanjian lain yang sudah di tentukan. ${ }^{17}$ Dan pada umumnya perselisihan mengenai harta bersama ini sering terjadi akibat salah satu pihak tidak ingin memberikan sebagian hartanya pada pihak yang lain, maka dengan demikian pihak yang lain akan menganggap sangat dirugikan dalam hal ini. ${ }^{18}$

Sehingga dapat disimpulkan jika sudah terjadi pemisahan harta benda atau harta bersama maka masing-masing setiap pihak harus mentaati isi dari persetujuan yang sudah dibuat tersebut, karena sesuatu yang berkaitan dengan pembagian hak nya secara gamblang dipisahkan, maka status harta dalam perjanjian perkawinan tidak akan ada lagi. Berkaitan dengan state of the art menurut penulis belum ditemukan pokok pembahasan yang sudah dijelaskan diatas, namun ditemukan ada beberapa penelitian yang memiliki kemiripan tetapi dengan permasalahan yang berbeda. Penelitian yang dimaksud yaitu dengan judul "Pertimbangan Hakim Terhadap Pembagian Harta Bersama Yang Telah Berpindah Hak Kepemilikan" yang ditulis oleh Mar'atus Solihah. Dalam penelitian tersebut hanya menjelaskan mengenai bagaimana dasar pertimbangan hakim dalam memutus harta bersama yang telah berpindah hak kepemilikannya namun tidak menjelaskan secara eksplisit mengenai bagaimana cara penyelesaiannya baik melalui pengadilan maupun diluar pengadilan. Penelitian ini sudah mengkaji bagaimana penyelesaian harta bersama dalam perkawinan dengan berbagai macam referensi sebagai bahan dalam penulisan dan penulis menyarankan cara yang terbaik adalah dengan cara kekeluargaan atau damai, namun dalam

14 Jannah, Maya. "PELAKSANAAN PEMBAGIAN HARTA BERSAMA DALAM PERKAWINAN SETELAH TERJADINYA PERCERAIAN (Studi kasus Putusan Pengadilan Agama Rantauprapat Nomor: 55/Pdt. G/2007/PA-RAP Di Pengadilan Agama Rantauprapat)." Jurnal Ilmiah Advokasi 2, no. 2 (2014): 47

15 Timur, Erma Kartika. "Pembagian Harta Bersama Perkawinan Dalam Perceraian Perkawinan Beda Agama Yang Dicatatkan." PhD diss., Universitas Brawijaya, (2017): 78

16 Pradoto, Muhammad Tigas. "Aspek Yuridis Pembagian Harta Bersama Dalam Perkawinan (Tinjauan Hukum Islam Dan Hukum Perdata)." Jurnal Jurisprudence 4, no. 2 (2017): 84

17 Maya Jannah., Op.Cit., 63

18 Tri Wahyudi Abdullah., Op.Cit., 61 
Undang-Undang yang berlaku belum mengatur secara tegas mengenai hal tersebut karena masih ada masyarakat yang merasa dirugikan akan ketidakadilan dan ketidakpastian hukum.

\section{Kesimpulan.}

Harta bersama terbentuk bersamaan pada saat terjadinya suatu perjanjian perkawinan. UU Perkawinan dan KUH Perdata hanya memuat mengenai pengertian dari harta benda didalam suatu perkawinan, namun tidak memaparkan penjelasan rinci. Didalam pemisahan harta bersama, kedua belah pihak terkadang harus mengikhlaskan sebagian hak yang dimiliki untuk mencapai kesepakatan bersama yang mufakat. Jika dilihat dari KUH Perdata, dan/atau UU Perkawinan rupanya tidak dibahas bagaimana harta bersama atas nama seorang, terkecuali pegelolaan harta bersama yang dibentuk pada masa perkawinan. Kedua belah pihak harus mentaati dan menghormati segala isi perjanjian kawin karena sesuatu yang mengenai pemisahan harta yang sudah jelas dipisahkan, sehingga tidak ada yang status nya adalah harta bersama. Penyelesaian Harta Bersama biasanya dilakukan dengan cara pemisahan harta benda. Dalam pelaksanaan pembagian harta bersama dilakukan karena ada berbagai faktor yang bermacam-macam. Penyelesaian perkara mengenai pembagian harta bersama yang terbaik adalah dilakukan dengan cara kekeluargaan, namun terkadang sering menimbulkan konflik antara kedua belah pihak. Penyelesaian permasalahan mengenai pemisahan harta bersama melalui jalur pengadilan, juga bisa diusulkan dengan pengajuan gugatan sendiri oleh pihak yang berperkara maupun perantara melewati pengacara hukum. Permohonan mengenai pemisahan harta bersama tidak bisa diajukan bersamaan dengan gugatan cerai.

Setiap bakal calon dan/atau pasangan suami istri dalam menjalani suatu kehidupan berumah-tangga, hendaknya memikirkan jangka panjang mengenai persoalan terkait bagaimana status dari harta bawaan maupun harta bersama para pihak serta kedudukan harta kekayaan yang diperoleh para pihak setelah perkawinan mereka, jika terjadi perceraian ataupun salah satu pihak meninggal dunia agar tidak terjadi konflik di lain hari.

\section{DAFTAR PUSTAKA}

Buku:

Ismatllah, Dedi. Hukum Perdata Islam Indonesia. (Bandung, Pustaka Setia, 2011).

Muhammad, Abdulkadir. Hukum dan Penelitian Hukum. (Bandung, PT Citra Aditya Bakti, 2014).

Muhammad, Abdulkadir. Hukum Perdata Indonesia. (Bandung, PT Citra Aditya Bakti, 2014).

Wahyudi, Tri Abdullah. Hukum Acara Peradilaan Agama. (Bandung, CV. Mandar Maju, 2018).

\section{Jurnal Ilmiah:}

Faizal, Liky. "Harta bersama dalam Perkawinan." Ijtimaiyya: Jurnal Pengembangan Masyarakat Islam 8, no. 2 (2015).

Firdawaty, Linda. "Filosofi Pembagian Harta Bersama." ASAS 8, no. 1 (2016). 
Istrianty, Annisa, and Erwan Priambada. "Akibat Hukum Perjanjian Perkawinan Yang dibuat Setelah Perkawinan Berlangsung." Privat Law 3, no. 2 (2016).

Jannah, Maya. "PELAKSANAAN PEMBAGIAN HARTA BERSAMA DALAM PERKAWINAN SETELAH TERJADINYA PERCERAIAN (Studi kasus Putusan Pengadilan Agama Rantauprapat Nomor: 55/Pdt. G/2007/PA-RAP Di Pengadilan Agama Rantauprapat)." Jurnal Ilmiah Advokasi 2, no. 2 (2014).

Kurniawan, Muhamad Beni. "Konsep Pembagian Harta Bersama Berdasarkan Kontribusi Dalam Perkawinan." AHKAM: Jurnal Ilmu Syariah 17, no. 2 (2017).

Makangiras, Aris Siswanto. "Prinsip-prinsip Hukum Harta Bersama Dalam Perkawinan Berdasarkan UU Nomor 1 Tahun 1974." Lex Privatum 2, no. 1 (2014).

Murniati, Rilda. "Pembaharuan Hukum Perjanjian Perkawinan Dan Akibat Hukumnya Terhadap Harta Dalam Perkawinan”, Jurnal Hukum Jatiswara 33, No. 3, (2018).

Pradoto, Muhammad Tigas. "Aspek Yuridis Pembagian Harta Bersama Dalam Perkawinan (Tinjauan Hukum Islam Dan Hukum Perdata)." Jurnal Jurisprudence 4, no. 2 (2017).

Rahajeng Pebriana Putu. "Fungsi Perjanjian Perkawinan Terhadap Status Kepemilikan Harta Pada Perkawinan Campuran", Kertha Semaya: Journal Ilmu hukum 6, No.11, (2018).

Timur, Erma Kartika. "Pembagian Harta Bersama Perkawinan Dalam Perceraian Perkawinan Beda Agama Yang Dicatatkan." PhD diss., Universitas Brawijaya, (2017).

\section{Peraturan Perundang - Undangan:}

Kitab Undang Undang Hukum Perdata Burgerlijk Wetboek, 2004, diterjemahkan oleh R.Subekti dan R. Tjitrosudibio, Pradnya Paramitha, Jakarta.

Undang Undang No. 1 Tahun 1974 Tentang Perkawinan, Lembaran Negara Republik Indonesia Tahun 1974 Nomor 1, Tambahan Lembaran Negara Republik Indonesia Nomor 3019. 